\title{
EVALUATION OF QUALITY INDICATORS FOR DRIED MELONS FROM UZBEKISTAN
}

\author{
Martins Sabovics $^{1 *}$, Shakhista Ishiyazova ${ }^{2}$, Lolita Tomsone ${ }^{1}$, Solvita Kampuse ${ }^{1}$, Hait Tilavov ${ }^{2}$, Toshtemir Ostonakulov ${ }^{2}$ \\ $I^{*}$ Department of Food Technology, Faculty of Food Technology, Latvia University of Life Sciences and Technologies, \\ Rigas iela 22, Jelgava, Latvia, e-mail: martins.sabovics@llu.lv \\ ${ }^{2}$ Samarkand Institute of Veterinary Medicine, Samarkand region, Mirzo Ulugbek street 77, Samarkand, Uzbekistan
}

\begin{abstract}
Melon is one of the most valuable and useful products, and it forces us to look for ways of processing these seasonal fruits for longterm storage. The easiest, cheapest and least time-consuming method of preservation is drying. The aim of the work was to study the effective methods of drying local varieties of melons and determine their quality indicators. As well as to study the quality indicators of dried melon obtained by the method of solar and artificial convective drying. The acceptance of dried melon samples, the content of total phenols, ascorbic acid (vitamin C), antioxidant activity, and the indicators of food safety and the microbiological background of dry products for several local melon varieties were studied. The highest total phenols content (TPC) in dried melon was detected in melon variety 'Oq uruq', but the highest antioxidant activity - in melon variety 'Obinavvot Samarqand' (DPPH') and 'Qundalang tur' $\left(\right.$ ABTS $\left.^{-+}\right)$. The melon variety as well as the drying method had a significant effect on TPC and antioxidant activity. The artificial convective drying productivity was higher: microbiological, sensory and chemical analysis of food safety showed that the products obtained by the artificial convective drying are better in all indicators than in the solar drying.
\end{abstract}

Keywords: melon, drying method, quality

\section{Introduction}

Uzbekistan is the world's leading producer of fruits and vegetables with annual production of more than 11 million tons. Melon, watermelon and pumpkin crops have extensive processing capabilities (Strategy of actions ..., 2018). More than 160 varieties of melons are currently grown in Uzbekistan, distinguished by precocity, yield, resistance to diseases and pests, and external environmental stress factors such as taste, preservation of quality, transportability, suitability for processing and drying. To date, 54 varieties of melons are included in the State Register of the Republic of Uzbekistan, of which 22 are early ripening, 19 are mid-season, 13 are late-ripening varieties (The state register..., 2018), the principal of which have been cultivated for several decades. Therefore, Uzbekistan is the leading melon-growing zone in Central Asia and 6 oases have been formed there - Khorezm, Bukhara, Samarkand, Tashkent, Fergana and Southern - for the cultivation of melons (Mavlyanova, 2005). Melon fruits have an original taste and beneficial properties. They contain 85-92\% water, 8-20\% dry matter, including, $0.8 \%$ protein, $1.8 \%$ fibre and $6.2 \%$ other carbohydrates, $0.9 \%$ fat, $0.6 \%$ ash, $20-30 \mathrm{mg} 100 \mathrm{~g}^{-1}$ of vitamin C, $0.03-0.07 \mathrm{mg} 100 \mathrm{~g}^{-1}$ of other vitamins, zinc, iron, calcium, magnesium, potassium, phosphorus and other trace elements, organic and mineral salts, and $31 \mathrm{kcal}$ energy (Solval et al., 2012; Amiri et al., 2014; Ostonakulov et al., 2016). Sugar content of individual melon varieties of Central Asia reaches 14-16\% (Ostonakulov et al., 2016). It is well known that melon peels and its seed oil are a good source of phenolic compounds. In addition, melon variety has various biological activities, such as antioxidant, antiinflammatory, anti-diabetic, antibacterial, as well as others that fully justify the presence of biologically active compounds (Silva et al., 2018).
Part of the biologically active substances is not stable due to technological processes applied, resulting in a reduction in the biological value of products (Tomsone et al., 2014). The method of drying also affects the composition and activity of biologically active substances in plants (Tomsone et al., 2013). The antioxidant activity and the content of phenolic compounds in mulberry leaves, after air-drying at $60{ }^{\circ} \mathrm{C}$ or below, did not differ significantly from that of mulberry leaves after freeze-drying. At the same time these parameters in mulberry leaves decreased significantly after being air-dried at $70{ }^{\circ} \mathrm{C}$ (Katsube et al., 2009). Dried melon is a healthy snack that contains great amount of minerals, antioxidants and vitamins (Berdiyev et al., 2009). Several scientists have been studying melon drying processes (Rodrigues, Fernandes, 2007; Chayjan et al., 2012; Solval et al., 2012; Darvishi et al., 2015). Therefore, experienced solutions have shown that the best way to preserve the taste and useful properties of a melon is to dry it - the easiest, cheapest and least laborious method of preservation. In addition, dried melon is successfully transportable and has a longer shelf-life. One of the fundamental principles that shape the quality of food products is to ensure their safety and preserve quality, as unhealthy chemical and biological compounds accumulated in products during storage, processing and sale can enter human body with food. Packaging materials have an importance in solving the problems of preserving the nutritional value and the biological safety of food throughout the entire way from production to sale to the consumer.

The aim of the research was to determine the effect of drying on the chemical, microbiological quality and safety of local melons varieties. As well as to study the quality indicators of dried melon obtained by the method of solar and artificial convective drying. 


\section{Materials and Methods}

The research was carried out in conjunction of the Samarkand Institute of Veterinary Medicine and Faculty of Food Technology, Latvia University of Life Sciences and Technologies.

\section{Characterisation of raw materials and drying process}

The following summer varieties (harvested in 2017-2018) with soft and firm mesocarps (edible part), early and medium ripe melons were tested:

○ A - 'Qundalang tur' (Cucumis melo L ssp. Rigidus (Pang.) Fil. Var. Bucharici);

○ B - 'Oq uruq' (Cucumis melo L ssp. Rigidus (Pang.) Fil. Var. Aestivales);

○ C - 'Obinavvot Samarqand' (Cucumis melo L ssp. Rigidus (Pang.) Fil. Var. Bucharici);

○ D - 'Kukcha-588' (Cucumis melo L ssp. Rigidus (Pang.) Fil. Var. Aestivales);

○ E - 'Ichi qizil' (Cucumis melo L ssp. Rigidus (Pang.) Fil. Var. Aestivales).

Sugar content was determined in fresh melons with a PAL-1 ATAGO refractometer (ATAGO Co Ltd., Japan).

After harvest, melon fruit was selected for cleaning from peel and seeds without any signs of spoilage, then the fruit was cut into 3-4 cm thick slices and dried. Two drying methods were used: solar (helio) drying in special open ventilated areas from 8 to 12 days and artificial convective drying (first at $\mathrm{t}=38-40^{\circ} \mathrm{C}$, for 4 6 hours, and then at $\mathrm{t}=75-80^{\circ} \mathrm{C}$, for $6-8$ hours) All samples were dried to achieve dry matter in the product not less than $18.2-20.0 \%$.

The acceptance of dried melon samples

The hedonic evaluation method was used based on ISO 4121:2003 standard. The 9-point hedonic scale ( 9 - extremely like, 1 - extremely dislike) was used to determine the acceptance rate of dried melon samples. The acceptance of dried melon samples was evaluated by 8 trained panellists.

\section{Microbiological and radionuclide analysis}

Microbiological studies were carried out at the accredited laboratory of the production association "Agromir". The number of mesophilic aerobic and facultative anaerobic microorganisms (total plate count) was determined according to GOST 10444.15-94 and expressed as colony forming units per gram.

The total content of radionuclides Cs-137, Sr-90 was determined according to radioactive substances in environmental objects (accreditation certificate No. UZ.AMT.07MAI-187 dated September 17, 2007).

\section{Chemicals}

Folin-Ciocalteu phenol reagent, gallic acid and 2,2-diphenyl-1-picrylhydraziyl (DPPH ${ }^{*}$ ) and were purchased from Sigma-Aldrich (Switzerland).

$\mathrm{Na}_{2} \mathrm{CO}_{3}, 2,2^{\prime}$-azino-bis(3-ethylbenz-thiazoline-6-sulfonic) $\left(\mathrm{ABTS}^{+}\right)$were obtained from Acros Organic (USA). L(+)-Ascorbic acid (176.13 $\mathrm{g} \mathrm{mol}^{-1}$ ), petroleum ether 80/110 were purchased from Chempur (Poland), but iodine concentrate $\left(0.05 \mathrm{~mol} \mathrm{~L}^{-1}\right)$ FIXANAL was obtained from Fluka Analytical, Sigma-Aldrich (Poland). Additional solvents as ethanol (96\%) and ultra-pure water were provided by Latvia University of Life Sciences and Technologies (Latvia, Jelgava).

Extraction procedure for total phenolic content (TPC) and antioxidant activity $(A A)$ assay

The homogenized sample, $2.00 \pm 0.01 \mathrm{~g}$ was extracted with $10 \mathrm{~mL}$ ethanol: water 80:20 (v/v) in an ultrasonic bath YJ5120-1 (Oubo Dental, USA) at $35 \mathrm{kHz}$ for 30 minutes at $20 \pm 1{ }^{\circ} \mathrm{C}$. The extracts were then centrifuged in a centrifuge CM-6MT (Elmi Ltd., Latvia) at $3500 \mathrm{~min}^{-1}$ for $5 \mathrm{~min}$. Residues were reextracted using the same procedure. After centrifugation, extracts were collected in a volumetric flask and filled to the mark with fresh solvent. The extraction process was carried out in triplicate. JENWAY 6300 spectrophotometer (Baroworld Scientific Ltd., UK) was used to determine TPC, scavenging activity of $\mathrm{DPPH}^{\circ}$ and $\mathrm{ABTS}^{\cdot+}$.

\section{Determination of total phenolic content (TPC)}

TPC of melon extracts was determined according to the method presented by Singleton et al. (1999). TPC was expressed as the gallic acid equivalents (GAE) $100 \mathrm{~g}^{-1}$ of sample.

\section{Determination of antioxidant activity $(A A)$}

AA was determined using the method presented by Yu et al. (2003) and Re et al. (1999). AA was expressed as $\mathrm{mM}$ TE $100 \mathrm{~g}^{-1}$ of sample.

The determination of ascorbic acid and total carotene content

Ascorbic acid content in dried melons was detected by iodine method T-138-15-01:2002 (Seglina, 2007) in four replications. The content of ascorbic acid was calculated according to formula (1):

$$
\mathrm{C}=5000 \times \frac{\mathrm{V}_{\text {sample }}}{\mathrm{m} \times \mathrm{V}_{\text {standard }}}
$$

where:

$\mathrm{V}_{\text {sample }}$ - volume of the iodine solution titrated in a sample, $\mathrm{mL}$;

$\mathrm{V}_{\text {standard }}$ - volume of the iodine solution titrated in a standard solution, $\mathrm{mL}$;

$\mathrm{m}$ - the amount of sample, $\mathrm{g}$.

Total carotene content was detected by spectrophotometric method using UV/VIS spectrophotometer Jenway 6705 (Bibby Scientific Ltd., UK) (Kampuse et al., 2015) with modifications. A sample of $2 \mathrm{~g}$ was mixed with $20 \mathrm{~mL}$ of ethanol and $10 \mathrm{~mL}$ of water. After $15 \mathrm{~min} 25 \mathrm{~mL}$ of petroleum ether was added and stirred for another hour. After mixing, samples were placed into darkness for the formation of two separate layers. The absorption of petroleum ether layer was measured at $440 \mathrm{~nm}(\mathrm{n}=3)$.

Statistical analysis

Experimental results were analysed by Microsoft Excel 2010. Statistical analysis were performed by Tomsone et al. (2014). 


\section{Results and Discussion}

The data obtained indicate (Table 1) that the yield of the studied melon varieties ranged from 25.0 to 32.8 tons per hectare, and an average of 28.9 tons.

Table 1

Sugar content and productivity of melon variety

\begin{tabular}{|c|c|c|c|c|}
\hline \multirow{2}{*}{ Sample } & \multirow{2}{*}{$\begin{array}{c}\text { Sugar } \\
\text { content, } \\
\%\end{array}$} & \multirow{2}{*}{ 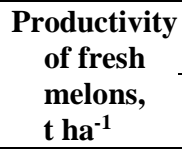 } & \multicolumn{2}{|c|}{$\begin{array}{c}\text { Productivity after } \\
\text { drying, } \mathrm{t} \mathrm{ha}^{-1}\end{array}$} \\
\hline & & & $\begin{array}{c}\text { solar } \\
\text { drying }\end{array}$ & $\begin{array}{l}\text { convective } \\
\text { drying }\end{array}$ \\
\hline $\mathrm{A}$ & $14.9^{b^{*}}$ & $27.5^{b}$ & $3.7^{\mathrm{c}}$ & $4.0^{\mathrm{c}}$ \\
\hline B & $12.2^{\mathrm{a}}$ & $25.0^{\mathrm{a}}$ & $2.7^{\mathrm{a}}$ & $2.9^{\mathrm{a}}$ \\
\hline $\mathrm{C}$ & $11.9^{\mathrm{a}}$ & $26.3^{\mathrm{a}}$ & $2.7^{\mathrm{a}}$ & $2.9^{\mathrm{a}}$ \\
\hline D & $13.5^{b}$ & $29.1^{b}$ & $3.3^{\mathrm{b}}$ & $3.6^{\mathrm{b}}$ \\
\hline$E$ & $10.8^{a}$ & $32.8^{c}$ & $3.0^{\mathrm{a}}$ & $3.4^{\mathrm{b}}$ \\
\hline
\end{tabular}

* The mean values in the same column, followed by different letters, vary significantly $(\mathrm{p}<0.05)$.

A - 'Qundalangi tur'; B - 'Oq uruq'; C - 'Obinavvot Samarqand'; D - 'Kukcha-588'; E - 'Ichi qizil'

Melon varieties differed in the sugar content, which varied from 10.8 to $14.9 \%$. The productivity of dried melons depended on the variety and methods of drying. The higher productivity of fresh melons was observed for sample $\mathrm{D}$ and $\mathrm{E}$, but after drying the highest productivity was for sample A (3.7-4.0 $\left.\mathrm{t} \mathrm{ha}^{-1}\right)$ and D (3.3-3.6 $\left.\mathrm{t} \mathrm{ha}^{-1}\right)$ were productivity decrease for $86.5 \%$ compare to fresh melon productivity. Comparing both drying methods, the convective drying gives by $0.6-1.3 \%$ higher productivity for all samples, compared to solar drying.

According to the hedonic scale, trained panellists evaluated samples of dried melon (Fig. 1) ranging from 7 (like moderately) to 9 (like extremely). The results showed that the panellists liked all dried melon samples which were dried by convective drying method ( $p>0.05)$. The quality of dried melon products during solar drying was estimated at 7.1-8.0 points, while convective drying - 7.9-8.9 points, which is 0.8-1.2 points higher than in the solar drying.

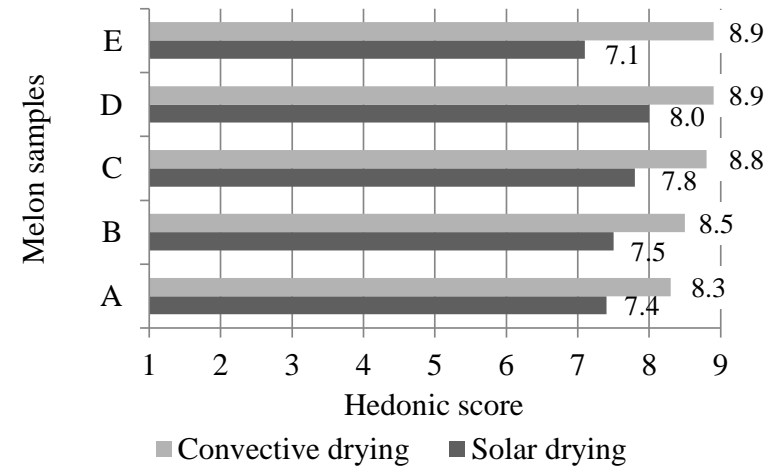

Figure 1. Evaluation results of dried melons using 9-point hedonic scale

A - 'Qundalangi tur'; B - 'Oq uruq'; C - 'Obinavvot Samarqand'; D - 'Kukcha-588'; E - 'Ichi qizil'

The panellists noted that the samples dried by convective drying method had retained a stronger melon aroma and taste compared to sun-dried samples. All convective dried samples and samples C and D from solar drying, degree of liking of which ranged from 7.8 to 8.9 (like very much to like extremely), were used for further analysis - microbiological and radionuclide testing, determination of total phenolic content, antioxidant activity and ascorbic acid content.

It was found that the total radionuclides content in the studied samples was below the acceptable concentration of $\mathrm{Cs}^{137}$ equal to $600 \mathrm{~Bq} \mathrm{~kg}{ }^{-1} ; \mathrm{Sr}^{90}-200 \mathrm{~Bq} \mathrm{~kg}{ }^{-1}$, respectively. The total radionuclides content in $\mathrm{Cs}^{137}$ samples ranged from 38.0 to $67.0 \mathrm{~Bq} \mathrm{~kg}^{-1}$, but $\mathrm{Sr}^{90}-$ from 20.0 to $50.0 \mathrm{~Bq} \mathrm{~kg}^{-1}$, which indicates that the radionuclides were below the acceptable concentration. Results of the microbiological evaluation of dried melon samples is shown in Table 2.

Table 2

Microbiological indicators of dried melon samples

\begin{tabular}{clcc}
\hline \multirow{2}{*}{$\begin{array}{c}\text { Melon } \\
\text { sample }\end{array}$} & \multicolumn{1}{c}{$\begin{array}{c}\text { Drying } \\
\text { method }\end{array}$} & $\begin{array}{c}\text { Total plate } \\
\text { count }\end{array}$ & Moulds \\
\cline { 3 - 4 } & \multicolumn{2}{c}{$\mathrm{CFU} \mathrm{g}^{-1}$} & $\mathrm{CFU} \mathrm{g}^{-1}$ \\
\hline $\mathrm{A}$ & Convective & $2 \times 10^{4}$ & $1 \times 10^{2}$ \\
$\mathrm{~B}$ & Convective & $2 \times 10^{4}$ & $1 \times 10^{2}$ \\
\hline \multirow{2}{*}{$\mathrm{C}$} & Convective & $2 \times 10^{4}$ & $2 \times 10^{2}$ \\
& Solar & $4 \times 10^{4}$ & $3 \times 10^{2}$ \\
\hline \multirow{2}{*}{$\mathrm{D}$} & Convective & $3 \times 10^{4}$ & $2 \times 10^{2}$ \\
& Solar & $4 \times 10^{4}$ & $3 \times 10^{2}$ \\
\hline $\mathrm{E}$ & Convective & $2 \times 10^{4}$ & $1 \times 10^{2}$ \\
\hline
\end{tabular}

A - 'Qundalangi tur'; B - 'Oq uruq'; C - 'Obinavvot Samarqand'; D - 'Kukcha-588'; E - 'Ichi qizil'

The acceptable concentration for total plate count is $5 \times 10^{4} \mathrm{CFU} \mathrm{g}^{-1}$, while acceptable concentration for moulds is $5 \times 10^{2} \mathrm{CFU} \mathrm{g}^{-1}$ (Sanitary norms ..., 2010). The obtained results in the analysed samples show that the microbiological indicators do not exceed the norm of acceptable concentration therefore the samples can be used in the diet. Only samples dried using the solar drying method had a higher total number concentration $\left(4 \times 10^{4} \mathrm{CFU} \mathrm{g}^{-1}\right)$ of microorganisms, which indicates that the product is more exposed to microbiological contamination by drying in the sun.

The TPC and other biologically active compounds in plants are influenced by variety, climate, precipitation, stage of development, harvest time (Marrelli et al., 2012; Tomsone et al., 2012). The environmental stress conditions such as extreme temperatures, ozone, dehydration etc. positively affect the TPC in fruits and vegetables (Capanoglu, 2010). As well as the technological processes used for the further processing, the chemical composition of fruits and vegetables is greatly influenced (Katsube et al., 2009; Tomsone et al., 2013).

Results of Tukey's test showed that variety and drying method has significant $(\mathrm{p}<0.05)$ influence on the TPC (Table 3). In general, the highest TPC was fixed in the melon samples after artificial drying. Samples of dried melons by artificial drying can be arranged depending on TPC as follows (starting with the largest): $\mathrm{B}>\mathrm{E}>\mathrm{C}$ $>\mathrm{D}>\mathrm{A}$. New compounds can be formed in the drying process. This is due to the oxidation reactions of 
glycoside hydrolysis or connection release cell of malfunction (Diaz-Moroto et al., 2002).

Table 3

Total phenolic content in dry melon depending on drying method and variety

\begin{tabular}{clc}
\hline \multirow{2}{*}{$\begin{array}{c}\text { Melon } \\
\text { sample }\end{array}$} & \multirow{2}{*}{ Drying method } & TPC \\
\cline { 3 - 3 } A & Convective & mg GAE 100g-1 \\
B & Convective & $88.11 \pm 4.82^{\mathrm{b}^{*}}$ \\
\hline \multirow{2}{*}{$\mathrm{C}$} & Convective & $96.52 \pm 5.88^{\mathrm{b}, \mathrm{c}}$ \\
& Solar & $90.26 \pm 5.28^{\mathrm{b}}$ \\
\hline \multirow{2}{*}{$\mathrm{D}$} & Convective & $90.34 \pm 3.17^{\mathrm{b}}$ \\
& Solar & $72.99 \pm 4.47^{\mathrm{a}}$ \\
\hline $\mathrm{E}$ & Convective & $107.64 \pm 3.54^{\mathrm{cd}}$ \\
\hline
\end{tabular}

$*$ The mean values in the same column, followed by different letters, vary significantly $(\mathrm{p}<0.05)$.

A - 'Qundalangi tur'; B - 'Oq uruq'; C - 'Obinavvot Samarqand'; D - 'Kukcha-588'; E - 'Ichi qizil'

There are contradictory data in the literature on the effect of drying on the content of phenolic compounds in plants. Some fruits, berries and vegetables that have been studied after drying have a higher TPC than fresh samples (Arslan, Musa Özcan, 2010; Yang et al., 2010). But in other plants, after drying, the TPC was lower than in fresh samples (Miean, Mohamed, 2001; Erbay, Icier, 2009). In the process of drying, plant tissues become fragile, causing rapid destruction of the cell walls and accelerating enzyme activity (Hossain et al., 2010). High enzyme activity can cause release of bound phenolic compounds. Some researchers have noticed a decrease in phenolic acid content due to drying and this is mainly due to enzymatic oxidation (Del Caro et al., 2004). Elevated temperatures and the effect of oxygen can cause rapid degradation of phenolic compounds in plant material (Igual et al., 2012).

Literature data show that the drying and freezing affect not only the content of biologically active substances in plants, but also the activity of antioxidants in fruits, berries and vegetables (Pinelo et al., 2004; Chan et al., 2009; Siriamornpun et al., 2012; Chan et al., 2013). ANOVA analysis of variance showed that the variety and the drying method have significant effect on antioxidant activity $(\mathrm{p}<0.05)$. The results of Tukey's test (Table 4) showed significant differences between the varieties. Samples of dried melons by artificial drying can be arranged depending on $\mathrm{DPPH}^{\circ}$ as follows (starting with the largest): $\mathrm{C}>\mathrm{E}>\mathrm{D}>\mathrm{B}>\mathrm{A}$.

By contrast, samples of dried melons by artificial drying can be arranged depending on $\mathrm{ABTS}^{-+}$as follows (starting with the largest): $\mathrm{A}>\mathrm{E}>\mathrm{C}>\mathrm{B}>\mathrm{D}$. The highest $\mathrm{DPPH}^{\circ}$ antioxidant activity was fixed for the sample $\mathrm{C}$, while $\mathrm{ABTS}^{\cdot+}$ assay showed higher results for the sample A. It was observed that the binding capacity of $\operatorname{ABTS}^{\circ+}$ cations is not related to the phenolic compounds present in the dried melons. This is especially evident in the sample A. Both the TPC and the activity of antioxidants are higher in artificial drying samples, except for $\mathrm{ABTS}^{\cdot+}$ activity for sample D ('Kukcha-588').
Comparing the results of TPC and antioxidant activity, it can be concluded that convective drying is a better drying method for preserving phenolic compounds with antioxidant activity.

Table 4

Analysis of antioxidant activity in dry melon depending on drying method and variety

\begin{tabular}{|c|c|c|c|}
\hline \multirow[b]{2}{*}{$\begin{array}{c}\text { Melon } \\
\text { sample }\end{array}$} & \multirow[b]{2}{*}{$\begin{array}{l}\text { Drying } \\
\text { method }\end{array}$} & DPPH' & ABTS $^{\bullet+}$ \\
\hline & & $\begin{array}{c}\mathrm{mM} T E \\
100 \mathrm{~g}^{-1}\end{array}$ & $\begin{array}{c}\mathrm{mM} T E \\
100 \mathrm{~g}^{-1}\end{array}$ \\
\hline $\mathrm{A}$ & Convective & $4.89 \pm 0.30^{\mathrm{bc} *}$ & $6.24 \pm 0.74^{\mathrm{c}}$ \\
\hline $\mathrm{B}$ & Convective & $4.99 \pm 0.06^{\mathrm{bcd}}$ & $4.93 \pm 0.24^{\mathrm{bcc}}$ \\
\hline \multirow{2}{*}{$\mathrm{C}$} & Convective & $5.42 \pm 0.22^{\mathrm{d}}$ & $5.70 \pm 0.47^{\mathrm{bc}}$ \\
\hline & Solar & $4.71 \pm 0.01^{\mathrm{b}}$ & $5.44 \pm 0.19^{\mathrm{bcc}}$ \\
\hline \multirow{2}{*}{ D } & Convective & $5.12 \pm 0.05^{\text {bcd }}$ & $4.22 \pm 0.49^{a}$ \\
\hline & Solar & $4.20 \pm 0.20^{\mathrm{a}}$ & $4.87 \pm 0.38^{\mathrm{bc}}$ \\
\hline $\mathrm{E}$ & Convective & $5.35 \pm 0.13^{\mathrm{cd}}$ & $6.14 \pm 0.64^{b c}$ \\
\hline
\end{tabular}

* The mean values in the same column, followed by different letters, vary significantly $(\mathrm{p}<0.05)$.

A - 'Qundalangi tur'; B - 'Oq uruq'; C - 'Obinavvot Samarqand'; D - 'Kukcha-588'; E - 'Ichi qizil'

Temperature is the most important factor influencing the drying rate of fruit and vegetables (Timoumi et al., 2004). Using solar drying method, the water evaporation process proceeds slower. Therefore, more time is available to continue internal biochemical reactions. As a result, various metabolic enzymes degrade biologically active compounds, including phenolic compounds. Therefore, solar dried melon samples contain lower TPC.

Table 5

The ascorbic acid and total carotenes content in dried melons

\begin{tabular}{clcc}
\hline \multirow{2}{*}{$\begin{array}{c}\text { Melon } \\
\text { sample }\end{array}$} & $\begin{array}{c}\text { Drying } \\
\text { method }\end{array}$ & $\begin{array}{c}\text { Ascorbic acid } \\
\text { content }\end{array}$ & $\begin{array}{c}\text { Total } \\
\text { carotenes } \\
\text { content }\end{array}$ \\
\cline { 3 - 4 } & mg 100 g-1 & mg 100 g $^{-1}$ \\
\hline A & Convective & $86.95 \pm 15.87^{\mathrm{d}^{*}}$ & $1.070 \pm 0.062^{\mathrm{e}}$ \\
$\mathrm{B}$ & Convective & $66.00 \pm 3.63^{\mathrm{b}}$ & $0.089 \pm 0.030^{\mathrm{c}}$ \\
\hline \multirow{2}{*}{$\mathrm{C}$} & Convective & $96.17 \pm 7.53^{\mathrm{d}, \mathrm{e}}$ & $0.101 \pm 0.005^{\mathrm{c}}$ \\
& Solar & $56.60 \pm 5.91^{\mathrm{b}}$ & $0.219 \pm 0.194^{\mathrm{cd}}$ \\
\hline \multirow{2}{*}{$\mathrm{D}$} & Convective & $88.34 \pm 6.40^{\mathrm{d}}$ & $0.095 \pm 0.004^{\mathrm{c}}$ \\
& Solar & $30.15 \pm 1.83^{\mathrm{a}}$ & $0.026 \pm 0.002^{\mathrm{a}}$ \\
\hline $\mathrm{E}$ & Convective & $72.71 \pm 2.07^{\mathrm{c}}$ & $0.037 \pm 0.003^{\mathrm{ab}}$ \\
\hline
\end{tabular}

* The mean values in the same column, followed by different letters, vary significantly $(\mathrm{p}<0.05)$.

A - 'Qundalangi tur'; B - 'Oq uruq'; C - 'Obinavvot Samarqand'; D - 'Kukcha-588'; E - 'Ichi qizil'

The amount of ascorbic acid in dried melons was from 30.15 to $96.17 \mathrm{mg} 100 \mathrm{~g}^{-1}$. The highest ascorbic acid content was in sample C ('Obinavvot Samarqand') by convective drying (Table 5). According to the literature data the ascorbic acid content in fresh melons is from 20 to $30 \mathrm{mg} 100 \mathrm{~g}^{-1} \mathrm{FW}$ (Lester et al., 2005; Ostonakulov et al., 2016), which means that, using artificial drying technologies ascorbic acid is quite stable while after solar drying of the same samples the ascorbic acid content was significantly $(\mathrm{p}<0.05)$ lower (Table 5). The total carotenes content (Table 5) in dried melons was in range from 0.026 to $1.070 \mathrm{mg} 100 \mathrm{~g}^{-1}$ and 
the evaluated varieties significantly differed. Evaluating different varieties of fresh melons, authors Laur and Tian (2011) also found large fluctuations of $\beta$-carotene

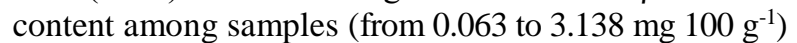
which proves the importance of variety. The drying technology did not show any clear tendency to changes of total carotenes content.

Correlation analysis (Table 6) was performed to determine connection between these parameters - TPC, ascorbic acid content (AAC), total carotenes content (TCC) and antioxidant activity ( $\mathrm{DPPH}^{*}$ and $\left.\mathrm{ABTS}^{-+}\right)$.

Table 6

Pearson's coefficients between total phenolic content and antioxidant activity for dried melon

\begin{tabular}{lccccc}
\hline & TPC & DPPH $^{*}$ & ABTS $^{++}$ & AAC & TCC \\
\hline TPC & 1 & & & & \\
DPPH $^{*}$ & $0.744^{* *}$ & 1 & & & \\
ABTS $^{+}$ & 0.335 & 0.397 & 1 & & \\
AAC & $0.464^{*}$ & $0.855^{* *}$ & 0.332 & 1 & \\
TCC & -0.148 & -0.045 & $0.477^{*}$ & 0.338 & 1 \\
\hline
\end{tabular}

** Correlation is significant at the 0.01 level (2-tailed).

* Correlation is significant at the 0.05 level (2-tailed).

In our study all correlations between analysed parameters are positive except total carotenes content with TPC and DPPH ${ }^{*}$ (Table 6). For dried melons, the correlation between TPC and AA (DPPH') was moderate $(r=0.744)$, but a closer correlation was observed between ascorbic acid content and antioxidant activity (DPPH'). Consequently, it can be concluded that phenol compounds and ascorbic acid in dried melons provide the (DPPH') antioxidant activity.

\section{Conclusions}

From the results it can be obtained that the best drying method for melons is artificial convective drying, which showed that the products obtained by artificial convective drying are better in all indicators than in the solar drying. Artificial convective drying method is better for preserving biologically active compounds and antioxidants in dried melons compared to solar drying method. In dried melons, phenolic compounds successfully act as antioxidants (DPPH ${ }^{*}$ method) for radical scavenging.

According to the results of the analysis, it is difficult to indicate which varieties of melons would be most suitable for drying, as the results for each melon variety are different. But obtaining the results of dried samples, a better result was given by variety - 'Qundalang tur' and 'Kukcha-588'.

\section{Acknowledgment}

We are very grateful to the Presidential Fund "Itedod" for the opportunity to take an internship at the Faculty of Food Technology, Latvia University of Life Sciences and Technologies (Ishniyazova Shakhista, from 09.28.2018. to 10.23.218), where, together with scientists from this university, research was carried out to determine the quality indicators of dried melon.

\section{References}

1. Amiri M., Tavakolipour H., Gharehyakheh S. (2014) Modeling of melon drying by application of microwave using mamdani fuzzy inference system. European Journal of Experimental Biology, Vol. 4 (1), p. 44-52.

2. Arslan D., Musa Özcan M. (2010) Study the effect of sun, oven and microwave drying on quality of onion slices. LWT-Food Science and Technology, Vol. 43, p. 1121-1127.

3. Berdiyev M., Arslan D., Özcan M. M. (2009) Nutritional composition, microbiological and sensory properties of dried melon: a traditional Turkmen product. International Journal of Food Science and. Nutrition, Vol. 60 (1), p. $60-68$.

4. Capanoglu E. (2010) The potential of priming in food production. Trends in Food Science and Technology, Vol. 21, p. 399-407.

5. Chan E. W. C., Lim Y. Y., Wong S. K., Lim K. K., Tan S. P., Lianto F. S., Yong M. Y. (2009) Effects of different drying methods on the antioxidant properties of leaves and tea of ginger species. Food Chemistry, Vol. 113, p. 166-172.

6. Chan E. W. C., Lye P. Y., Eng S. Y., Tan Y. P. (2013) Antioxidant properties of herbs with enhancement effects of drying treatments: A synopsis. Free Radicals and Antioxidants, Vol. 3, p. 2-6.

7. Chayjan R.A., Agha-Alizade H.H., Barikloo H., Soleymani B. (2012) Modeling some drying characteristics of cantaloupe slices. Cercetari Agronomice Moldova XLV, Vol. 2 (150), p. 5-14.

8. Darvishi H., Khodaei J., Azadbakht M. (2015) The parameters of mass transfer of convective drying in sliced melon. Philippine Agricultural Scientist, Vol. 98 (1), p. 360-372.

9. Del Caro A., Piga A., Pinna I., Fenu P. M., Agabbio M. (2004) Effect of drying conditions and storage period on polyphenolic content, antioxidant capacity and ascorbic acid of prunes. Journal of Agricultural and Food Chemistry, Vol. 52, p. 4780-4784.

10. Diaz-Moroto M. C., Perez-Coello M. S., Cabezudo M. D. (2002) Effect of different drying methods on the volatile compounds of parsley (Petroselium crispum L.). European Food Research and Technology, Vol. 215, p. 227-230.

11. Erbay Z., Icier F. (2009) Optimization of drying of olive leaves in a pilot-scale heat pump dryer. Drying Technology, Vol. 27(3), p. 416-427.

12. Hossain M. B., Barry-Ryan C., Martin-Diana A. B., Brunton N. P. (2010) Effect of drying method on the antioxidant capacity of six Lamiaceae herbs. Food Chemistry, Vol. 123, p. 85-91.

13. Igual M., García-Martínez E., Martín-Esparza M. E., Martínez-Navarrete N. (2012) Effect of processing on the drying kinetics and functional value of dried apricot. Food Research International, Vol. 47, p. 284-290.

14. Kampuse S., Ozola L., Straumite E., Galoburda R. (2015) Quality parameters of wheat bread enriched with pumpkin (Cucurbita Moschata) by-products. Acta Universitatis Cibiniensis. Series E: Food Technology, Vol. 19(2), p. 3-14.

15. Katsube T., Tsurunaga Y., Sugiyama M., Furuno T., Yamasaki Y. (2009) Effect of air-drying temperature on antioxidant capacity and stability of polyphenolic compounds in mulberry (Morus alba L.) leaves. Food Chemistry, Vol. 113(4), p. 964-969.

16. Laur L. M., Tian L. (2011) Provitamin A and vitamin C contents in selected California-grown cantaloupe and 
honeydew melons and imported melons. Journal of Food Composition and Analysis, Vol. 24 (2), p. 194-201.

17. Lester G. E., Jifon J. L., Rogers G. (2005) Supplemental foliar potassium applications during muskmelon fruit development can improve fruit quality, ascorbic acid, and beta-carotene contents. Journal of the American Society for Horticultural Science, Vol. 130(4), p. 649-653.

18. Marrelli M., Menichini F., Statti G. A., Bonesi M., Duez P., Menichini F., Conforti F. (2012) Changes in the phenolic and lipophilic composition, in the enzyme inhibition and antiproliferative activity of Ficuscarica L. cultivar Dottato fruits during maturation. Food and Chemical Toxicology, Vol. 50, p. 726-733.

19. Mavlyanova R.F. (2005) Melons of Uzbekistan. Tashkent: PGRI www.ipgri.cgiar.org ISBN 978-92-9043-711-6 ISBN 92-9043-711-6. $206 \mathrm{p}$.

20. Miean K. H., Mohamed H. (2001) Flavonoid (myricetin, quercetin, kaempferol, luteolin and apigenin) content of edible tropical plants. Journal of Agricultural and Food Chemistry, Vol. 49(6), p. 3106-3112.

21. Ostonakulov T.E., Sanaev S.T., Khamdamova E.I. (2016) Samarkand melons. Samarkand: Navruz. 39 p.

22. Ostonakulov, T.E., Zuev V.I., Kodirkhuzhaev O.K. (2016). Vegetable. Tashkent: Navruz. 552 p.

23. Pinelo M., Rubilar M., Sineiro J., Nunez M. J. (2004) Extraction of antioxidant phenolics from almond hulls (Prunus amygdalus) and pine sawdust (Pinus pinaster). Food Chemistry, Vol. 85(2), p. 267-273.

24. Re R., Pellegrini N., Proteggente A., Pannala A., Yang M., Rice-Evans C. (1999) Antioxidant activity applying an improved ABTS radical cation decolorization assay. Free Radical Biology and Medicine, Vol. 26, p. 1231-1237.

25. Rodrigues S., Fernandes F. A. N. (2007) Dehydration of melons in a ternary system followed by air-drying. Journal of Food Engineering, Vol. 80, p. 678-687.

26. Sanitary norms, rules and hygienic standards of the Republic of Uzbekistan. (2010) Hygienic requirements for food safety. SanPin RUz № 0283-10. Official Edition. Tashkent.

27. Seglina D. (2007) Sea buckthorn fruits and their processing products. Summary of promotion work for acquiring the Doctor's degree in Engineering Sciences in the Food Science. Jelgava, Latvia, $48 \mathrm{p}$.

28. Silva M. A., Albuquerque T. G., Alves R. C., Oliveira M. B. P. P., Costa H. S. (2018) Melon (Cucumis melo L.) by-products: Potential food ingredients for novel functional foods? Trends in Food Science and Technology, In press, Corrected Proof, Available online 26 July 2018.

29. Singleton V. L., Orthofer R., Lamuela-Raventos R. M. (1999) Analysis of total phenols and other oxidation substrates and antioxidants by means of Folin-Ciocalteu reagent. Methods in Enzymology, Vol. 29, p. 152-178.
30. Siriamornpun S., Kaisoon O., Meeso N. (2012) Changes in colour, antioxidant activities and carotenoids (lycopene, b-carotene, lutein) of marigold flower (Tagetes erecta L.) resulting from different drying processes. Journal of Functional Foods, Vol. 4, p. 757-766.

31. Solval K.M., Sundararajan S., Alfaro L., Sathivel S., (2012) Development of cantaloupe (Cucumis melo) juice powders using spray drying technology. LWT-Food Science and Technology, Vol. 46, p. 287-293.

32. Strategy of actions in five priority directions of development of the Republic of Uzbekistan in 2017-2021. Presidential Decree -5308 of 22.01.2018. On the State Program National database of legislation, 01.23.2018, No. 06/18/ 5308/0610; 05/25/2018, No. 06/18/5447/1269. [accessed on 02.01.2018.]. Available at: http://lex.uz/docs/3516841

33. The state register of crops recommended for sowing in the territory of the Republic of Uzbekistan. (2018) Ministry of Agriculture and Water Resources of the Republic of Uzbekistan. The State Commission for the Testing of various varieties of crops. Tashkent. p. 54-56.

34. Timoumi S., Mihoubi D., Zagrouba F. (2004) Simulation model for a solar drying process. Desalination, Vol. 168, p. 111-115.

35. Tomsone L., Kruma Z. (2014) Influence of freezing and drying on the phenol content and antioxidant activity of horseradish and lovage. In: 9th Baltic conference on food science and technology "Food for consumer well-being" FOODBALT 2014 Conference proceedings. Jelgava, Latvia, p. 192-197.

36. Tomsone L., Kruma Z., Galoburda R., Dimins F., Kreicbergs V. (2013) Influence of technological processes on the phenol content and antioxidant properties of horseradish roots (Armoracia rusticana L.). In: 2nd International conference on Nutrition and Food Sciences "Chemical, Biological and Environmental Engineering" International Conference proceedings, Moscow, Russia, Vol. 53. p. 6-10.

37. Tomsone L., Kruma Z., Lepse L. (2012) Influence of genotype and harvest time on the phenolic content of horseradish (Armoracia rusticana L.) roots. In: Research for rural development 2012: annual 18th international scientific conference proceedings, Latvia University of Agriculture. Jelgava: LLU, 2012. Vol.1, p. 124-130.

38. Yang J., Chen J., Zhao Y., Mao L. (2010) Effects of drying processes on the antioxidant properties in sweet potatoes. Agricultural Sciences in China, Vol. 9(10), p. 1522-1529.

39. Yu L., Haley S., Perret J., Harris M., Wilson J., Haley S. (2003) Antioxidant properties of bran extracts from Akron wheat grown at different locations. Journal of Agriculture and Food Chemistry, Vol. 51, p. 1566-1570. 